\title{
Notes on the Seasonal Dynamics of Some Paederinae (Coleoptera: Staphylinidae) Species in the Vineyards of Manisa, Western Anatolia
}

\author{
Sinan ANLAŞ ${ }^{1 *} \quad$ Hüseyin YENER ${ }^{2} \quad$ Ersen Aydın YAĞMUR ${ }^{3}$ \\ ${ }^{1,2,3}$ Alaşehir Vocational School, Manisa Celal Bayar University, TR-45600, Alaşehir, Manisa, \\ TURKEY \\ E-mails: ${ }^{1 *}$ sinan.anlas@gmail.com, ${ }^{1 *}$ sinan.anlas@cbu.edu.tr, ${ }^{2}$ huseyin.yener@cbu.edu.tr, \\ 3ersen.yagmur@gmail.com \\ ORCID IDs: ${ }^{1} 0000-0001-7059-5677,{ }^{2} 0000-0001-7363-2242,{ }^{3} 0000-0002-0396-3975$
}

\begin{abstract}
Paederinae (Coleoptera: Staphylinidae) specimens were collected via two light traps which were established in a vineyard in Sarıgöl district of Manisa between April 15th and November 15th in 2018-2019 in this study. Thus, the densities and seasonal activities of the species obtained were evaluated. At the end of the study, a total of 7.274 specimens were identified based on seven species, which are Astenus melanurus (Küster, 1853), A. procerus (Gravenhorst, 1806), Luzea graeca (Kraatz, 1857), Medon dilutus pythonissa (Saulcy, 1865), Paederus fuscipes Curtis, 1826, Scopaeus bicolor Baudi Di Selve, 1848 and S. debilis Hochhuth, 1851. It seems all recorded species are predators. The most abundant species are S. debilis with 7.006 specimens and $P$. fuscipes with 204 specimens. The identified species were found to be intense and active especially from mid-May to the end of July in general. According to the observations during field studies, it was found that $P$. fuscipes species was a predator of Aphis illinoisensis Shimer, 1866 and A. gossypii Glover, 1877 (Homoptera, Aphididae) species. This species is most active at the beginning and the end of dry summer.
\end{abstract}

Key words: Light trap, Paederinae, Paederus fuscipes, S. debilis, predator, Turkey, Vitis vinifera.

Anlaş, S., Yener, H., \& Yağmur, E.A. (2021). Notes on the seasonal dynamics of some Paederinae (Coleoptera: Staphylinidae) species in the vineyards of Manisa, Western Anatolia. Journal of the Entomological Research Society, 23(2), 121-132. 


\section{INTRODUCTION}

Turkey provides opportunity for the production of agricultural products due to its climatic and geographical characteristics. One of these products is grape. Although grape (Vitis vinifera Linnaeus, 1753) is a plant grown in many places worldwide, its homeland is Anatolia and its neighboring regions. Therefore, it is grown in many different geographical regions of Turkey. Turkey is ranked sixth in the world in grape production and about $30 \%$ of the vineyard area is located in Manisa province in Turkey (Semerci, Kızılıtuğ, Çelik, \& Kiracı, 2015). There are many insects which damage the grape plant. Therefore, many studies have been carried out on insects which damage the grape plant because of its economic importance. For that reason, mostly insecticides have been used in the control against grape plant pests. However, studies on the determination of natural enemies of grape plant pests and their potential for use in pest control are extremely limited.

Staphylinidae is represented by about 65.000 species in 33 subfamilies in the worldwide, is the largest family of the Coleoptera order (Newton, 2017; Irmler, Klimaszewski, \& Bethz, 2018). Paederinae, one of the largest subfamilies of this family, is represented by more than 6,000 species, belonging to 225 genera (Herman, 2001). The species belonging to the Paederinae subfamily are found in almost all habitats, but mostly in moist areas. However, they are generally abundantly found in stream, lake and riversides, moist grassy areas, humic parts of the soil and agricultural areas. As many of the Paederinae species are predators, they are agriculturally beneficial.

Since some of the Paederinae species exhibit light-directed behavior, it is possible to collect and examine them by light traps. However, studies on the collection and evaluation of Paedarinae species with light traps are very few. These studies are generally faunistic studies and ecological studies are very limited. Few ecological studies on Paederinae species have been conducted by Bohac \& Bezdek (2004), Abdullah \& Sina (2009), Nasir, Akram, \& Ahmed (2012), Tezcan \& Anlaş (2009), Özgen, Anlaş, \& Eren (2010) and Anlaş, Özgen, Yağmur, \& Örgel (2017).

Although it is known that some of the Paederinae species are predators, it is not known which Paederinae species are the predators of which pest species. In addition, no specific study has been conducted with light traps on these species up to date. It is known that among Paederinae subfamily Paederus species, which is also of medical importance, and especially Paederus fuscipes Curtis, 1826 species, are abundant in agricultural areas (cotton, cereal, rice, corn and various vegetable fields) and that they are predators of many pests of such genera as Corcyra spp. (Lepidoptera, Pyralidae), Heliothis spp. (Lepidoptera, Noctuidae) and Aphis spp. (Homoptera, Aphididae) and therefore they are known to be useful for agriculture (Berglind, Ehnstram, \& Ljungberg, 1997; Krakerb, Van Huis, Van Lenterenb, Heonge, \& Rabbingea, 2000; Komala-Devi, Yadav, \& Anand, 2003; Nasir et al, 2012). Apart from this, no study has been found regarding which invertebrate species are preys of Paederinae species. However, some species have been stated to be general pradators, as mentioned. For example, it has been observed that Achenium depressum (Gravenhorst, 1802) and Scopaeus 
Notes on the Seasonal Dynamics of Some Paederinae Species

mitratus Binaghi, 1935 are known as predators in cotton fields (Garcia-Ruiz et al, 2018), Paederus limnophilus Erichson, 1840, Paederidus rubrothoracicus (Goeze, 1777 ) and $P$. ruficollis (Fabricius, 1775) are known as general predators in agricultural areas (Kolasa, Kubisz, Mazur, Scibior, \& Kajtoch, 2018).

No specific studies on Paederinae species found in vineyards have been conducted up to now. In this study, Paederinae species in vineyard areas were collected for the first time with the aid of light traps in Sarıgöl district, Manisa, western Anatolia. It was attempted to reveal the seasonal activities of the identified species, by determining the density of the collected specimens according to the species. It is also aimed to determine the presence of predatory Paederinae species.

\section{MATERIAL AND METHODS}

In this study, light traps were used to determine which Paederinae species occur in a selected vineyard area in Sarıgöl District, Manisa province. This area is located in Western Anatolia, includes in the Mediterranean climate, which is characterized by dry, hot summers and mild, moist winters. Average temperature and average rainfall amount of studied localities are provided in Fig. 1. Two light traps were set between April 15th and November 15th in 2018-2019 with a two-year study.

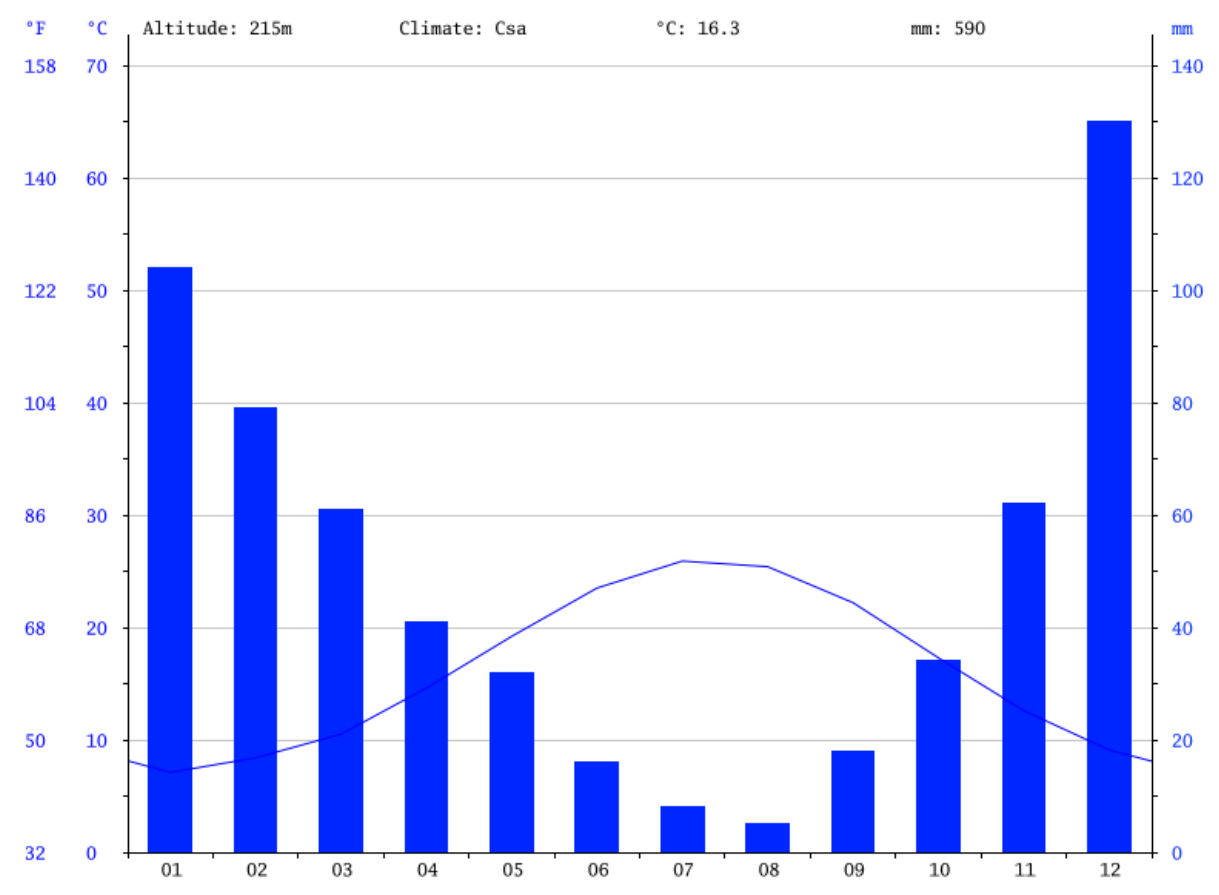

Fig. 1. Avarage temperature and average rainfall amount in Sarıgöl District, Manisa, Turkey (Source: tr.climate-data.org). 
The vineyard area is 9 da in total and has a coarse textured soil. The vineyard has 3-year-old "Thompson seedless" grape variety. The planting space is $3.00 \times 1.8$ meters and it was set with semi pergola training system. All cultural practices in the vineyard were done under farmer conditions. Light traps were set at $38^{\circ} 14^{\prime} 18.93^{\prime \prime} \mathrm{N}$, $28^{\circ} 42^{\prime} 25.35^{\prime \prime} E$ and $38^{\circ} 14^{\prime} 19.57^{\prime \prime} N 28^{\circ} 42^{\prime} 29.38^{\prime \prime} E$ (Fig. 2). A 60 watt Philips energy saver white day light bulb was used at each trap and traps were cleared at two weeks' intervals.

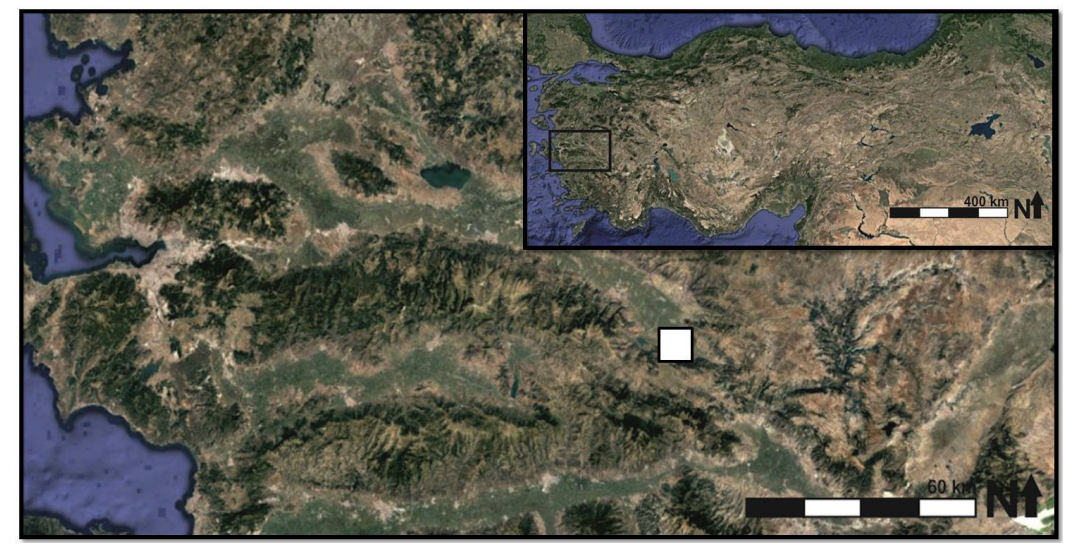

Fig. 2. The locality of light trapping study area in Sarıgöl, Manisa, Turkey.

In the vineyard area where the study was carried out, insecticide was applied against Anaphothrips vitis Priener in April and May, against Lobesia botrana Denis \& Schiffermüller in May, June and July and against Planococcus citri Risso in May and June by spraying. Unlike 2018, a broad spectrum insecticide with Deltamethrin effective substance was used in the first application (on 12.05.2019) for L. botrana in 2019.

The morphological studies were conducted using a Stemi 508 microscope (Zeiss, Germany). The photographs of the habitus, forebody and aedeagus of the studied species were taken with a digital camera (Zeiss Axiocam ERC5s). All photographs were edited with the Helicon Focus v. 6, and Coreldraw X5 software. The map was made using the software Google Earth Pro (2019). The materials were identified by the first author and were deposited in the Alaşehir Zoological Museum, Manisa, Turkey (AZMM).

\section{RESULTS}

\section{Species composition}

In this study, Paederinae samples were collected through two light traps set in a vineyard area in Sarıgöl district, Manisa, western Anatolia between April 15 and November 15, in 2018-2019. At the end of the study, a total of 7.274 specimens were collected to seven species. These species are Astenus melanurus (Küster, 1853), A. procerus (Gravenhorst, 1806), Luzea graeca (Kraatz, 1857), Medon dilutus pythonissa (Saulcy, 1865), Paederus fuscipes Curtis, 1826, Scopaeus bicolor Baudi Di Selve, 1848 and S. debilis Hochhuth, 1851 (Table 1). 
Notes on the Seasonal Dynamics of Some Paederinae Species

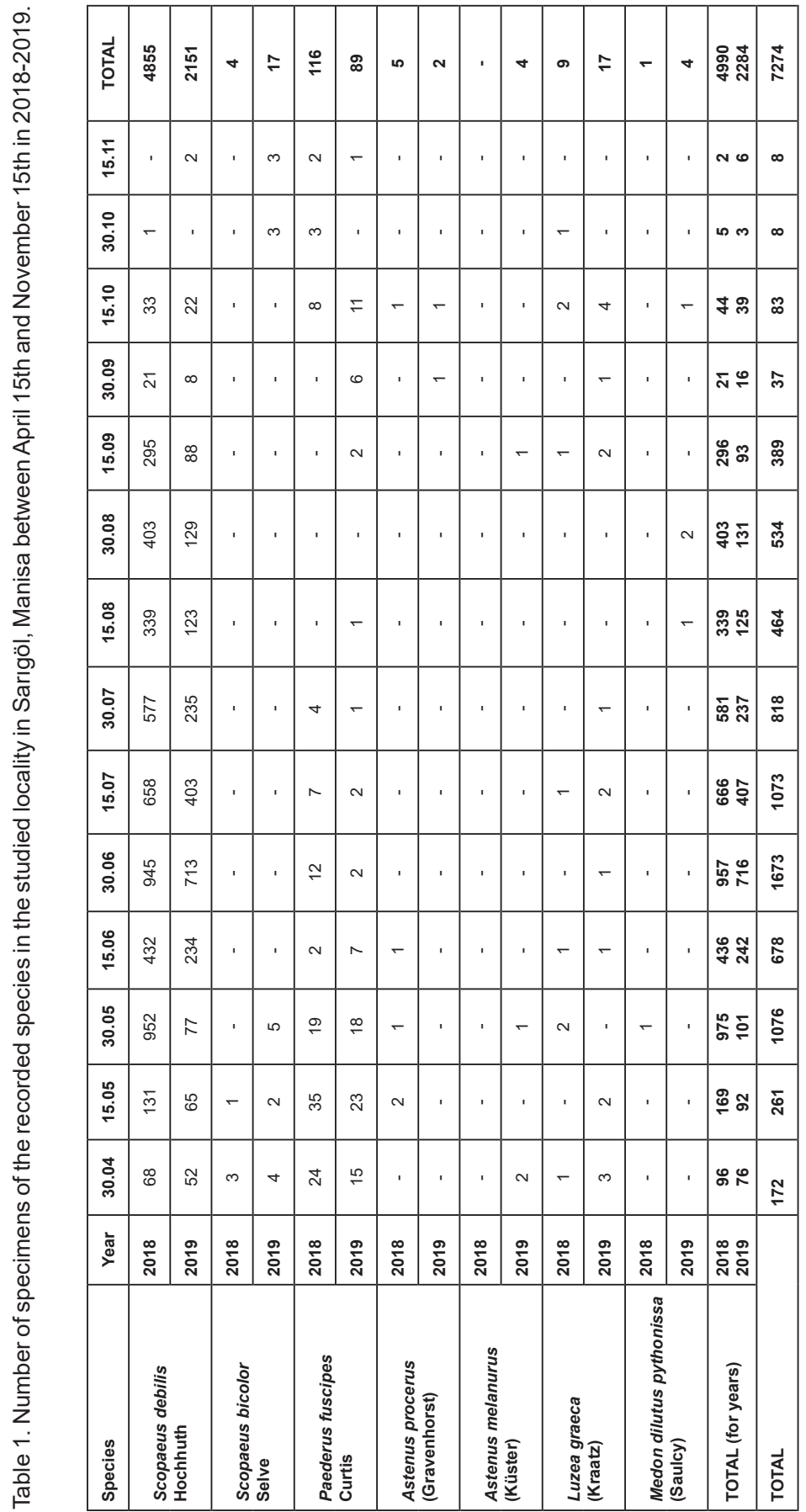


When the specimen numbers of the identified species were examined, it was observed that most specimens belong to $S$. debilis (Fig. 3; for more illustrations of this species see Frisch, 1999) with 7.006 specimens. Belonging to this species, 4.855 specimens were collected in 2018 and 2.151 in 2019. Following this species, the most abundant species is $P$. fuscipes (Fig. 4) with a number of 204 specimens. Others than these two species were examined, it was observed that very few specimens belonging to these species could be collected. For this reason, it is thought that these species are found incidentally in Sarıgöl vineyards or are represented by very few specimens. When these species and the number of the collected specimens were examined; 26 specimens of $L$. graeca species, 21 specimens of $S$. bicolor species, seven specimens of $A$. procerus species, five specimens of $M$. dilutus pythonissa and lastly four specimens of $A$. melanurus species were determined.
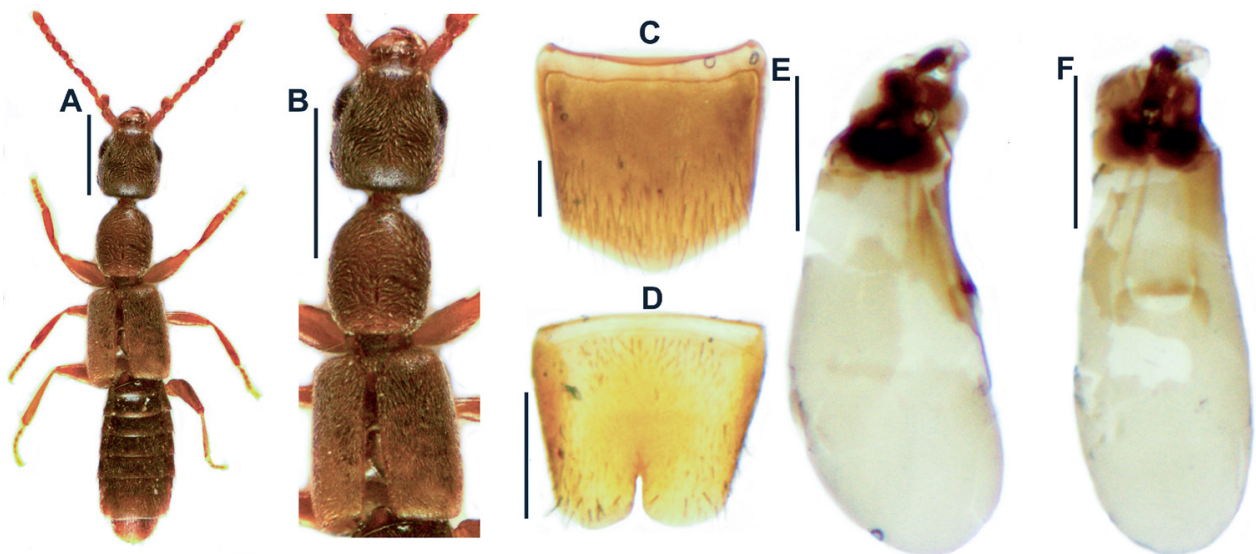

Fig. 3. Scopaeus debilis Hochhuth, 1851. A-habitus; B-forebody; C-male sternite VII; D-male sternite VIII; E-aedeagus, lateral view; F-aedeagus, ventral view. Scale bars: $0.5 \mathrm{~mm}(\mathrm{~A}-\mathrm{B}) ; 0.2 \mathrm{~mm}(\mathrm{C}-\mathrm{F})$.

\section{Seasonal dynamics}

It was seen that most specimens belong to the species $S$. debilis. Considering the distribution of the specimens by months, it was observed that the most samples for the year 2018 fell into the traps at the end of May with a number of 952 samples. At the end of June, this number was 945 specimens. Only one specimen was collected at the end of October and none in mid-November. Evaluating the year 2018 in general, it was seen that 68 samples were captured on April 30, then the number of samples increased until May 30 , then decreased to 432 and then increased again and reached 945 on June 30. After that, it was observed that the number of specimen decreased and reached 658 on July 15, and then continued to decrease 577 on July 30 , and decreased to 339 on August 15. It was seen that 403 specimens were collected with very little growth in the following period, and then the samples collected decreased gradually and no samples were collected on November 15. When the year 2019 was evaluated, it was observed that the period in which most specimens were collected 
Notes on the Seasonal Dynamics of Some Paederinae Species

was the end of June. In this period, 713 samples were collected. No sample could be collected on October 30. When the seasonal activity of the species was examined, 2018 and 2019 were found to be almost the same (Fig. 5).
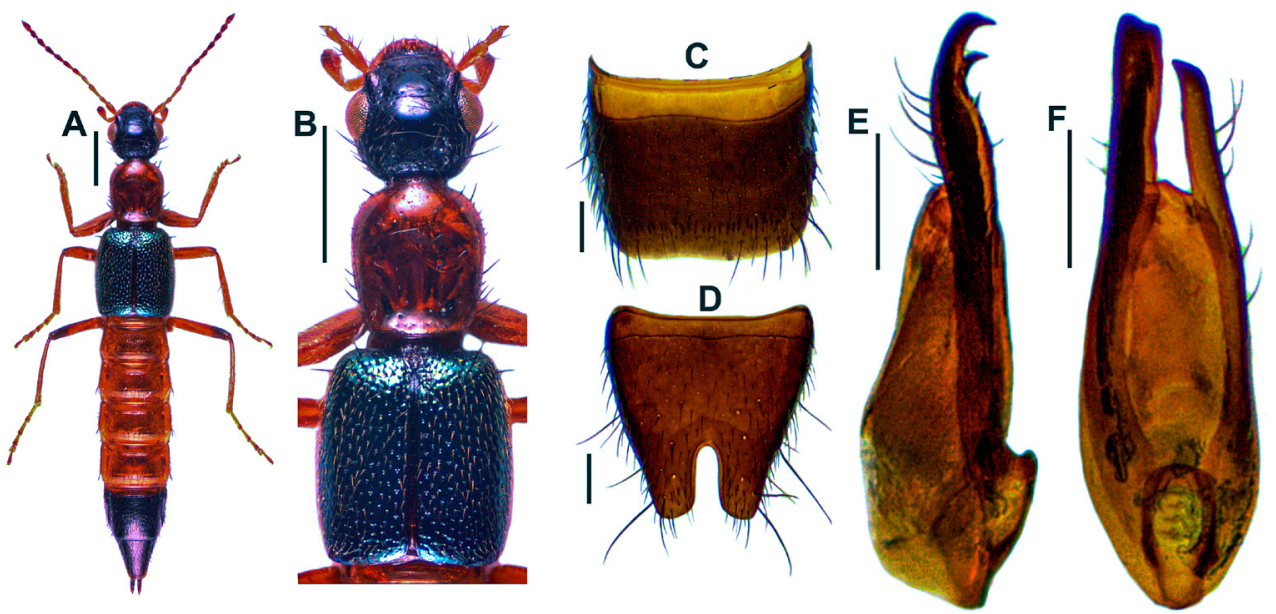

Fig. 4. Paederus fuscipes Curtis, 1826. A-habitus; B-forebody; C-male sternite VII; D-male sternite VIII; E-aedeagus, lateral view; F-aedeagus, ventral view. Scale bars: $1 \mathrm{~mm}(\mathrm{~A}-\mathrm{B}) ; 0.2 \mathrm{~mm}(\mathrm{C}-\mathrm{F})$.

$P$. fuscipes species is the most caught species after $S$. debilis. 116 specimens belonging to this species were recorded in 2018 and 88 in 2019. When the seasonal activity of the species was analysed, it was observed that most number specimens fell into the traps in April and May, few or no specimens fell into the traps during summer months and that the number of specimens in autumn months was still higher than the summer though it was not as much as spring months (Fig. 5). The seasonal activity of the P. fuscipes species was previously investigated by Anlaş et al (2017) for the Aegean Region, and due to few samples obtained in this study, it could not be fully compared with the previous results. According to this study, it was observed that the numbers of $P$. fuscipes species began to increase as of May, reached a high level at the beginning and in the middle of June, decreased in the dry period, that is July and August, and reached the highest numbers at the beginning and in the middle of September (Anlaş et al, 2017).

Accordingly, as a result of this study, it was detected that the density of $P$. fuscipes specimens collected with the help of light traps are almost similar to Anlaş et al (2017). The most important difference is that few samples were collected in the Sarigöl vineyard areas during autumn months. When other recorded species were examined after $S$. debilis and $P$. fuscipes species, it was observed that very few specimens of these species were collected. For this reason, it is thought that these species are found incidentally in Sarıgöl vineyard areas or are represented by very few specimens. Seasonal activities could not be evaluated appropriately due to few specimens of these species. 

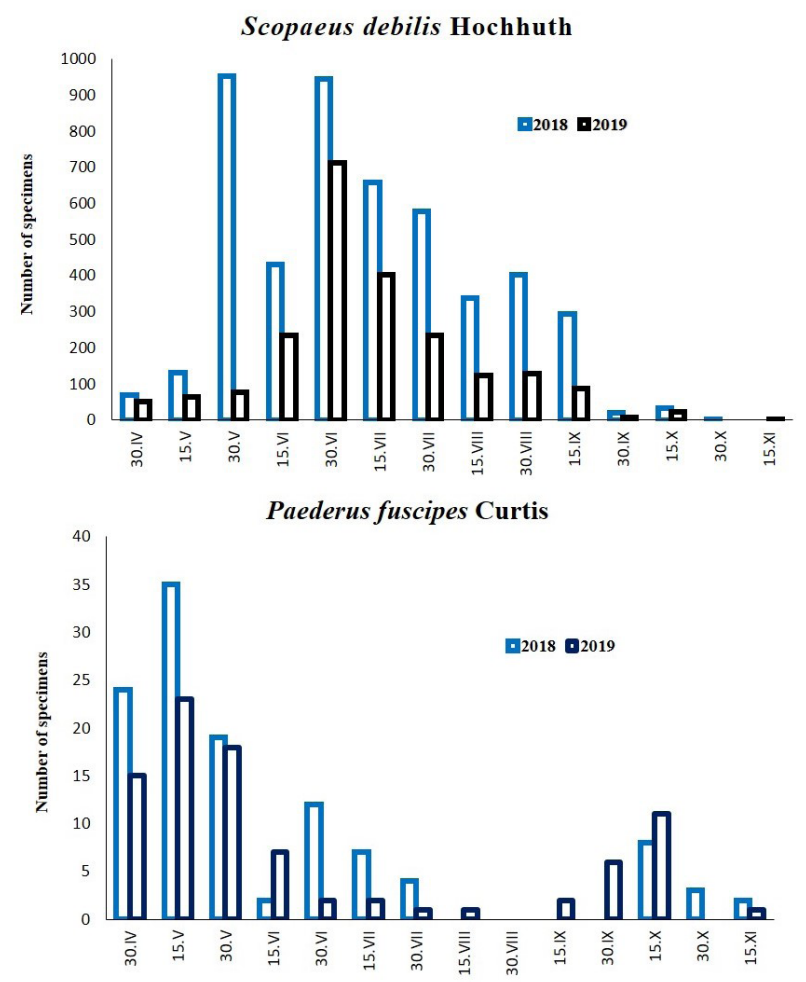

Fig. 5. Seasonal dynamics of Scopaeus debilis and Paederus fuscipes in the vineyard in Sarıgöl, Manisa between April 15th and November 15th in 2018-2019.

When the seasonal activities of the species in Sarıgöl vineyards were evaluated in both 2018 and 2019 together by considering all the samples of the seven species determined at the end of this study, it was seen that a total of 172 specimens were caught at the end of April, which was the first collection. After that, it was found that in the middle of May, the number increased to 261, after that, at the end of May, the number of the samples collected increased significantly to 1.076. After this date, the number of samples decreased to 678 in the collection in mid-June. By the end of June, it was observed that the most specimens were collected in this period by 1673 . Then, the number of specimens fell to 1073 and then to 818 . After that, the number of specimens continued to decrease in the middle of August and fell to 464 and at the end of the month, it reached 534 specimens with a small increase. In the collection made in the middle of September, the number of collected specimens decreased again to 389 specimens, then the number of the specimens decreased further, first to double digit numbers and then to eight specimens in late October and mid November. To sum up, it was understood that they reached the highest numbers at the end of May and June, they were also present in the summer months and their numbers were gradually decreasing in the autumn months. 
Notes on the Seasonal Dynamics of Some Paederinae Species

\section{Observations on recorded species}

Apart from the light traps set within the scope of the study, various survey studies were carried out in the vineyard area in an attempt to observe the obtained species. As a result of the field studies, it was seen that the Paederinae species in the vineyard area were not active during the daytime and their full activities started in the evening and night hours. Accordingly, the bottom parts of the stones in the vineyard and its surrounding areas, the underneath of the barks and the leaves, the surroundings of the weeds and the areas where they can hide were investigated during the daytime. As a result of the investigation, some species belonging to Staphylinidae family were found in these areas and it was observed that these species were generally different from the species caught by light traps. The species identified in these areas were generally species of Ocypus spp., Philonthus spp. and Quedius spp. (Staphylinidae, Staphylininae) The species belonging to these genera are generally those which live on the soil and feed on small invertebrates, but no related species have been collected by light traps. Some of the identified Paederinae species were observed, though in small numbers, on and around the grape plant.

Accordingly, it has been observed that $P$. fuscipes species is active at night but it can be found in moist or wet areas around the vineyard during the day. It has been also observed that this species attack especially nymphs, sometimes adult plant lice, that is Aphis species. Two of these aphid species have been determined and identified as Aphis illinoisensis Shimer, 1866 and A. gossypii Glover, 1877 (Homoptera, Aphididae).

Some observations have been made regarding $S$. debilis species, which are the most abundant within the study. It was observed that this species attacked the nymphs of the A. illinoisensis species, similarly $P$. fuscipes. However, according to observations, $P$. fuscipes was found to be more predatory than $S$. debilis. The reason for this may be the fact that $P$. fuscipes has a larger body than $S$. debilis and carries a strong toxic substance in its hemolymph. However, existence of this species in small numbers in the vineyards restricts its effectiveness. Apart from this, no other observations could be made with the other species, which are $A$. melanurus, A. procerus, L. graeca, M. dilutus pythonissa and $S$. bicolor. The reason for this may be that these species exist in small numbers in the vineyard. However, as it is very difficult to distinguish between $S$. bicolor species and $S$. debilis species in the field with the naked eye, it is thought that $S$. bicolor species may also attack these pests in addition to the $S$. debilis species, which are thought to be predators of the above mentioned species. In addition, in a few observations, some Reduviidae (Heteroptera) species have been observed to attack $S$. debilis species.

\section{DISCUSSION}

This study, which was carried out between 2018-2019 in order to determine predator Paederinae species in Sarıgöl vineyards and to monitor their seasonal activities, is the first study of its kind in Turkey. As a result of the study, a total of seven species have been determined. These species are Astenus melanurus (Küster), Astenus procerus 
(Gravenhorst), Luzea graeca (Kraatz), Medon dilutus pythonissa (Saulcy), Paederus fuscipes Curtis, Scopaeus bicolor Baudi Di Selve and Scopaeus debilis Hochhuth. A few studies related to the collection of samples by using only light traps have been conducted in Turkey so far on this subject.

When the species identified in these studies were compared to other studies on rove beetles, it was observed that $M$. dilutus pythonissa, $P$. fuscipes and $S$. bicolor species were collected through light traps from organic cherry orchards in Kemalpaşa (Izmir) in the study previously conducted by Tezcan \& Anlaş (2009). While S. debilis Hochhuth species was determined to be the dominant species in this study, it was seen that the dominant species was $S$ bicolor in the study conducted by Tezcan \& Anlaş (2009).

In another study, Özgen et al (2010) determined eight species belonging to the Paederinae subfamily with light traps in pistachio and cotton fields in Diyarbakır, Batman, Siirt and Mardin provinces in the Southeastern Anatolia Region. The species of $A$. melanurus and $P$. fuscipes collected in that study were also found in our study. Apart from this, while Luzea graeca species was found in our study, Luzea nigritula (Erichson, 1840) species of the same genus, was found in the study conducted by Özgen et al (2010). Likewise, in our study, M. dilutus pythonissa species was found, while in this study Medon semiobscurus (Fauvel, 1875) species of the same genus was found. It has been seen that in the study published by Özgen et al (2010), the most abundantly found species was Scopaeus ebneri Scheerpeltz, 1929.

Anlaş et al (2017), studied on the seasonal activity of $P$. fuscipes Curtis, which is an important species regarding medical and public health terms, in the Aegean Region, found this species in abundance from many light trap localities. This species, which is also useful in agriculture, was identified in this study. However, in our study, it was seen that this species could not be collected in large numbers. According to Nasir et al (2012), this species is affected by intensive agricultural spraying. Considering the intensive insecticide applications of Sarıgöl vineyard areas, where the project was carried out, this result could be considered normal. Nasir et al (2012) collected $P$. fuscipes with different methods in his study in many agricultural fields in Pakistan. A large number of specimens of this species were recorded with the help of one of these methods, that is light trap. In the light of the samples collected, the seasonal activity of the species in Pakistan was discussed. They also stated that $P$. fuscipes fed on aphids and other soft-bodied insects and carmine spider mites and larvae of fruit flies. In this study, it was found that this species attacked some types of aphids, too. In their study in the Czech Republic, Bohac \& Bezdek (2004) determined 26 species belonging to Staphylinidae using light trap. It is understood that only the $P$. fuscipes species belongs to the Paederinae subfamily. However, it is seen in that study that this species is not abundant and not dominant. Apart from that, it is stated that the light trap can be used as an effective method to capture Staphylinidae species.

Except for Paederinae species, a large number of species of Aleocharinae (Aleochara sp., Atheta sp., Drusilla sp., Oxypoda sp.), Pselaphinae, Tachyporinae (Mycetoporus sp. Tachinus, Tachyporus sp.), Oxytelinae (Anotylus sp., Bledius sp., Carpelimus sp., Platysetethus sp.), Steninae (Stenus sp.) and Staphylininae (Gabrius 
Notes on the Seasonal Dynamics of Some Paederinae Species

sp., Philonthus sp., Platydracus sp., Quedius sp., Xantholinus sp.) subfamilies were also collected in this study. However, as most of them could not be identified in terms of species level, they could not be evaluated in this study.

At the end of the study, while 4.990 specimens were collected in 2018, 2.284 specimens were found in 2019 . Hereby, it was observed that the number of specimens collected in 2018 constituted $68.6 \%$ of the total material, while this rate remained at $31.4 \%$ in 2019 . It is believed that the number of specimens collected in 2019 was less than the previous year, due to climatic causes and especially insecticide applications made before some collection periods. It is thought that the reason for the low number of samples collected on May 30, 2019 in the study compared to 2018 is due to the use of non-selective deltamethrin active ingredient-containing insecticide. The seasonal activities of the detected species in general show us that the predator Paederinae species are especially intense and active from mid-May to the end of July. The number of specimens collected in this period was remarkably higher than other periods. When the species and abundances obtained as a result of the study are evaluated in general, Paederinae species diversity in the Sarıgöl vineyards is considered to be weak. It has been determined that there are few other species other than $S$. debilis species, which is predominantly present and constitutes $96.3 \%$ of all samples. The most intense among these is $P$. fuscipes with 204 specimens. Although there is little Paederinae species diversity in the Sarigöl vineyard areas, there are many dominant predator species of Staphylinidae (e. g. Aleochara sp., Ocypus sp., Philonthus sp., Quedius sp., Xantholinus sp., Tachyporus sp.). This is considered important as it shows that this area has not yet lost its biodiversity.

\section{ACKNOWLEDGMENTS}

We would like to thank Dr. S. Örgel (Alaşehir), S. Yaman (Akhisar) and Doruk Köksal (Aydın) for their contributions and Fatma Musluoğlu (Alaşehir) for proof-reading the English manuscript. This study was supported by the Manisa Celal Bayar University Scientific Research Projects Coordination Unit (BAP, project no. 2018- 095).

\section{REFERENCES}

Abdullah, F. \& Sina, I. (2009). Rove beetles (Coleoptera: Staphylinidae) of lanjak entima sarawak, east Malaysia. International Journal of Zoological Research, 5, 126-135.

Anlaş, S., Özgen, İ., Yağmur, E.A., \& Örgel, S. (2017). Notes on seasonal dynamics of Paederus fuscipes Curtis, 1826 in western Anatolia, Turkey (Insecta: Coleoptera: Staphylinidae: Paederinae). Ecologia Balkanica, 9, 29-37.

Berglind, S.A., Ehnstram, B., \& Ljungberg, H. (1997). Riparian beetles biodiversity and stream flow regulationthe example of svartan and Mjallan streams. Central Sweden. Entomologisk-Tidskrift, 118, 137-154.

Bohac, J. \& Bezdek, A. (2004). Staphylinid beetles (Coleoptera, Staphylinidae) recorder by pitfall and light trapping in Mrtvy Luh peat bog. Silva Gabreta, 10, 141-150.

Frisch, J. (1999). A revision of the Scopaeus debilis species group, with description of a new species from Madagascar (Coleoptera, Staphylinidae, Paederinae). Revue Suisse de Zoologie, 106, 361-383. 
Garcia-Ruiz, E., Loureiro, I. Farinos, G.P., Gomez, P., Gutierrez, E., Sanchez, F.J., Escorial, M.C., Felix, O., Chueca, M.C., \& Castanera, P. (2018). Weeds and ground-dwelling predators response to two different weed management systems in glyphosate-tolerant cotton: A farm-scale study. Plos One, 13, 1-18.

Herman, L.H. (2001). Catalog of the Staphylinidae (Insecta: Coleoptera). 1758 to the end of the second millennium. Volumes I-VII. Bulletin of the American Museum of Natural History, 265, 1-4218.

Irmler, U., Klimaszewski, J., \& Bethz, O. (2018). Introduction to the biology of rove beetles, 1-4, In O., Bethz, U., Irmler, \& J., Klimaszewski, (Eds.). Biology of rove beetles (Staphylinidae). Life History, Evolution, Ecology and Distribution (pp. 351). Springer International Publishing.

Kolasa, M., Kubisz, D., Mazur, M.A., Scibior, R., \& Kajtoch, L. (2018). Wolbachia prevalence and diversity in selected riverine predatory beetles (Bembidiini and Paederini). Bulletin of Insectology, 71, 193-200.

Komala-Devi, P., Yadav, D.N., \& Anand, J. (2003). Predatory behaviour and feeding potential of Paederus fuscipes. Indian Journal of Entomology, 65, 319-323.

Krakerb, J., Van Huis, I.A., Van Lenterenb, J.C., Heonge, K.L., \& Rabbingea, R. (2000). Identity and relative importance of egg predators of rice leaffolders (Lepidoptera: Pyralidae). Biological Control, 19, 215-222.

Nasir, S., Akram, W., \& Ahmed, F. (2012). The Population Dynamics, Ecological and Seasonal Activity of Paederus fuscipes Curtis (Staphylinidae; Coleoptera) in the Punjab, Pakistan, 36-41. 2nd International Conference on Asia Agriculture and Animal, 258 pp.

Newton, A.F. (2017). Nomenclatural and taxonomic changes in Staphyliniformia (Coleoptera). Insecta Mundi, 0595, 1-52.

Özgen, I., Anlaş, S., \& Eren, S. (2010). Contribution to the knowledge of Staphylinidae (Coleoptera) fauna of cotton and pistachio fields in Southeastern Anatolia. Journal of Anatolian Natural Sciences, 1, 9-16.

Semerci, A., Kızılıtuğ, T., Çelik, A.D., \& Kiracı, M.A. (2015). Türkiye bağcılığının genel durumu. Mustafa Kemal Üniversitesi Ziraat Fakültesi Dergisi, 20, 42-51. (in Turkish)

Tezcan, S. \& Anlaş, S. (2009). Notes on the light trap collected rove beetles (Coleoptera: Staphylinidae) of the integrated cherry orchards of western Turkey. Turkish Journal of Entomology, 33, 3-11. 